\title{
Michael-type addition of azoles of broad-scale acidity to methyl acrylate
}

\author{
Sławomir Boncel ${ }^{* 1}$, Kinga Saletra ${ }^{1}$, Barbara Hefczyc ${ }^{2}$ \\ and Krzysztof Z. Walczak"1
}

\section{Letter}

\section{Address:}

${ }^{1}$ Silesian University of Technology, Department of Organic Chemistry, Bioorganic Chemistry and Biotechnology, Krzywoustego 4, 44-100 Gliwice, Poland, Tel.: +48 32237 1792, Fax: +48 322372094 and ${ }^{2}$ Silesian University of Technology, Department of Chemical Organic Technology and Petrochemistry, Krzywoustego 4, 44-100 Gliwice, Poland, tel.: +48 3223710 32, fax: +4832 2371032

\section{Email:}

Sławomir Boncel ${ }^{*}$ - slawomir.boncel@polsl.pl;

Kinga Saletra - kingasaletra@gmail.com;

Barbara Hefczyc - barbara.hefczyc@polsı.pl;

Krzysztof Z. Walczak ${ }^{*}$ - krzysztof.walczak@polsı.pl

* Corresponding author

Keywords:

imidazole derivatives; methyl acrylate; Michael-type addition; pyrazole derivatives; 1,2,4-triazole derivatives

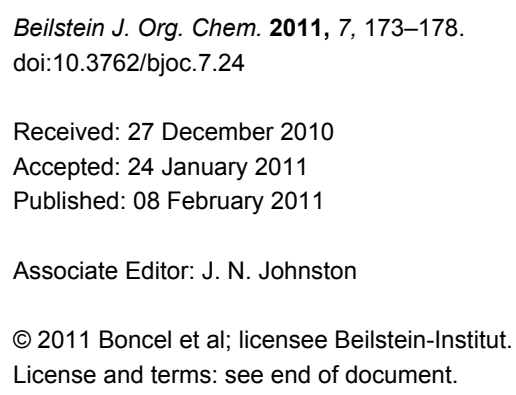

\begin{abstract}
An optimisation of Michael-type addition of azole derivatives of broad-scale acidity - ranging from 5.20 to $15.00 \mathrm{p} K_{\mathrm{a}}$ units namely 4-nitropyrazole, 3,5-dimethyl-4-nitropyrazole, 4(5)-nitroimidazole, 4,5-diphenylimidazole, 4,5-dicyanoimidazole, 2-methyl-4(5)-nitroimidazole, 5(4)-bromo-2-methyl-4(5)-nitroimidazole and 3-nitro-1,2,4-triazole to methyl acrylate as an acceptor was carried out. The optimisation process involved the use of an appropriate basic catalyst (DBU, DIPEA, NaOH, NaH, TEDA), a donor/base/acceptor ratio and the reaction temperature. The reactions were performed in DMF as solvent. Target Michael adducts were obtained in medium to excellent yields. Importantly, for imidazole and 1,2,4-triazole derivatives, no corresponding regioisomers were obtained.
\end{abstract}

\section{Introduction}

Derivatives of azoles are important biologically active compounds. Many, especially those containing imidazole, pyrazole and 1,2,4-triazole moieties, constitute building blocks for a variety of therapeutic agents (Figure 1).
1,2-Arylimidazole derivatives, e.g., 2-(3-chloro-4-methylphenyl)-1-phenyl-4-(trifluoro-methyl)imidazole (I) are selective cyclooxygenase (COX-2) inhibitors [1]. Metronidazole (2-(2methyl-5-nitroimidazol-1-yl)ethanol) is an antibiotic and 

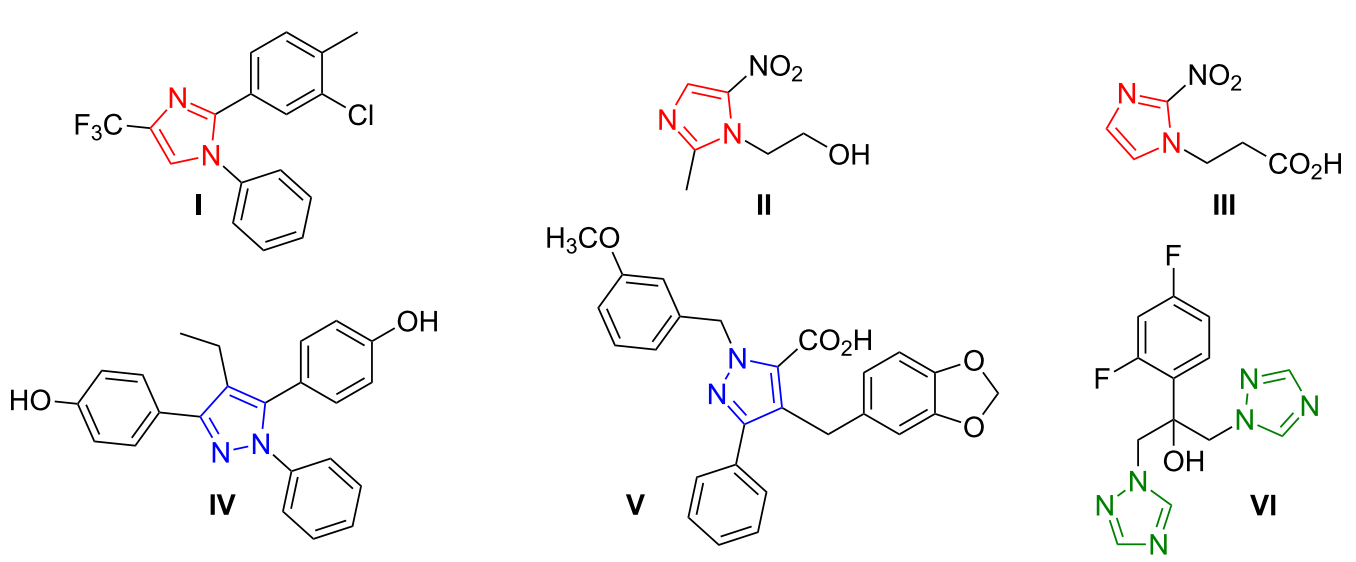

Figure 1: Examples of azole derivatives as important therapeutic agents.

antiprotozoal agent whose uses include, among others, the treatment of anaerobic bacterial infections [2]. Complexes of Co(II) and $\mathrm{Cu}(\mathrm{II})$ with 3-(2-nitroimidazol-1-yl)propanoic acid (III) are radiosensitisers in cancer therapy [3]. 4,4'-(4-Ethyl-1phenylpyrazole-3,5-diyl)diphenol (IV) and its derivatives are known modulators of receptors regulating the secretion of estrogens crucial in the pathogenesis of breast cancer [4]. 4-(Benzo[d][1,3]dioxol-5-ylmethyl)-1-(3-methoxybenzyl)-3phenyl-pyrazole-5-carboxylic acid (V) is an antagonist of endothelial receptors and is used as a clinical regulator of the cardiac cycle [5]. Fluconazole (VI) 2-(2,4-difluorophenyl)-1,3bis(1,2,4-triazol-1-yl)propan-2-ol is an antifungal drug used in the treatment and prevention of superficial and systemic fungal infections [6].

The base-catalysed Michael-type addition reaction of various azoles to $\alpha, \beta$-unsaturated carbonyl and nitro derivatives has been frequently exploited in the synthesis of precursors of biologically active compounds $[3,7-15]$. This reaction, although structurally restricted to $\alpha, \beta$-unsaturated carbonyl compounds and their analogues, is advantageous due to its higher regioselectivity compared to alkylation reactions using alkyl halides [16-19], alkyl sulfates [20] or oxiranes [18] under basic conditions, or alcohols over zeolites [21]. Moreover, it is usually described as a green-chemistry with an effective synthetic protocol and a simple work-up. In the Michael-type additions of azole $\mathrm{N}-\mathrm{H}$ acids, numerous catalysts such as $\mathrm{KF} / \mathrm{Al}_{2} \mathrm{O}_{3}$ [8], $\mathrm{CeCl}_{3} \cdot 7 \mathrm{H}_{2} \mathrm{O} / \mathrm{NaI}$ [9], $\mathrm{NaH}$ or $\mathrm{ZnCl}_{2}$ [10], $\mathrm{K}_{2} \mathrm{CO}_{3}$ [11], anhydrous $\mathrm{K}_{3} \mathrm{PO}_{4}$ [12], $\left(\mathrm{NH}_{4}\right)_{2} \mathrm{Ce}\left(\mathrm{NO}_{3}\right)_{6}(\mathrm{CAN})$ [22] or ionic liquids, e.g., $\mathrm{Cu}(\mathrm{acac})_{2}$ immobilised in [bmim] $\left[\mathrm{BF}_{4}\right][15]$ have been used. Other reaction conditions including enzymatic catalysis (Bacillus subtilis) [13], zinc-active-site acylases from Escherichia coli and Aspergillus oryzae [23] as well as ultrasonic irradiation in the presence of montmorillonite [14] have also been reported. In addition, there has been several recent reports on the synthesis of Michael-type adducts of azoles by the use of microwave irradiation [7,24]. The optimisation of aza-Michael reactions with $N$-methylimidazole as the base catalyst was published in 2007 by Liu et al [25]. However, when this catalyst was used with azoles of narrower-scale acidity $\left(\mathrm{p} K_{\mathrm{a}}\right.$ range from 8.93 to 15.1 ) including imidazole and its 2- and 4(5)-methyl, 4(5)-nitro-, 2-methyl-4(5)-nitro- derivatives as well as with 1,2,4-triazole, there was no evidence for a regioselective course of the reactions. Furthermore, extremely high acidic azoles, which are substrates for many important drugs, have seldomly been considered as aza-Michael donors due to their poor nucleophilicity and the possible tendency of adducts to undergo retro-Michael reactions [26].

Here, we present Michael-type addition of azoles, inter alia imidazole and 1,2,4-triazole derivatives of high acidity $\left(\mathrm{p} K_{\mathrm{a}} \leq\right.$ $6.05)$, to methyl acrylate under optimised conditions (temperature, type of base and donor/base/acceptor ratio) as a regioselective, efficient and useful reaction for the formation of adducts that can be utilised in the synthesis of more complex systems including intermediates for the pharmaceutical industry[27].

\section{Results and Discussion}

4-Nitropyrazole (1a), 3,5-dimethyl-4-nitropyrazole (1b), 4(5)nitroimidazole (1c), 4,5-diphenylimidazole (1d), 4,5dicyanoimidazole (1e), 2-methyl-4(5)-nitroimidazole (1f), 4(5)bromo-2-methyl-5(4)-nitroimidazole (1g) and 3-nitro-1,2,4-triazole (1h) were used as Michael donors. The azoles derivatives (1a-h) were subjected to the reaction with methyl acrylate (2) (Michael acceptor) in the presence of an appropriate base, namely DBU $\left(\mathrm{p} K_{\mathrm{a}}=12\right.$ [28]), diisopropylethylamine (DIPEA, Hünig's base, $\mathrm{p} K_{\mathrm{a}}=10.75$ [29]), $\mathrm{NaOH}$ ( $\mathrm{p} K_{\mathrm{a}}=15.7$ [30]), $\mathrm{NaH}$ $\left(\mathrm{p} K_{\mathrm{a}}=37\right.$ [29]) or TEDA $\left(\mathrm{p} K_{\mathrm{a}}=8.82\right.$ [31]) in polar aprotic (DMF) or protic $(\mathrm{MeOH})$ solvent (Scheme 1, Table 1). Although the above $\mathrm{p} K_{\mathrm{a}}$ values were determined in water, their 


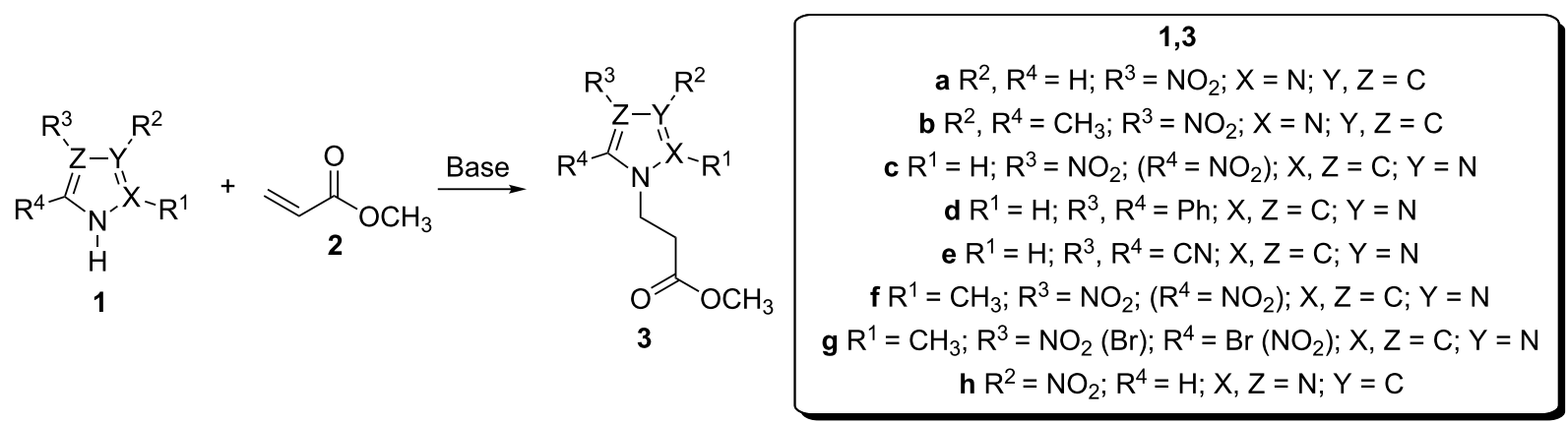

Scheme 1: Michael-type addition of azoles of broad-scale acidity $\mathbf{1 a - h}$ to methyl acrylate (2) under basic conditions.

Table 1: Optimised conditions of Michael-type addition of azoles of broad-scale acidity $\mathbf{1 a}-\mathbf{h}$ to methyl acrylate (2), physical properties and yields of the products $\mathbf{3 a}-\mathbf{h}$.

\begin{tabular}{|c|c|c|c|c|c|c|c|}
\hline \multirow{2}{*}{1} & \multirow{2}{*}{$\mathrm{p} K_{\mathrm{a}}\left(\mathrm{H}_{2} \mathrm{O}\right)$} & \multicolumn{5}{|c|}{ Conditions } & \multirow{2}{*}{$\begin{array}{c}3 \\
\text { Yield [\%] }\end{array}$} \\
\hline & & $\mathrm{A} / \mathrm{D}$ & Base & Base / A & $T\left[{ }^{\circ} \mathrm{C}\right]$ & $t[\mathrm{~h}]$ & \\
\hline \multirow{2}{*}{$\mathbf{a}$} & \multirow{2}{*}{$9.67[34]$} & $1: 1$ & DBU & 1.0 & 20 & 1 & 31 \\
\hline & & $2: 1$ & DIPEA & 1.0 & 20 & 5 & 97 \\
\hline \multirow{2}{*}{ b } & \multirow{2}{*}{15.00 [35] } & $1: 1$ & DBU & 1.0 & 20 & 1 & 54 \\
\hline & & $2: 1$ & DIPEA & 1.0 & 20 & 24 & 98 \\
\hline \multirow{2}{*}{ c } & \multirow{2}{*}{$8.93[36]$} & $1: 1$ & DBU & 1.0 & 20 & 2 & 30 \\
\hline & & $1.1: 1$ & DIPEA & 1.0 & 20 & 12 & 98 \\
\hline \multirow{5}{*}{ d } & \multirow{5}{*}{$5.70^{a}[37]$} & $4: 1$ & DIPEA & 1.0 & 20 & 192 & 0 \\
\hline & & $4: 1$ & DIPEA & 1.0 & 80 & 48 & 0 \\
\hline & & $1: 1$ & $w / o^{b}$ & - & 60 & 168 & 0 \\
\hline & & $4: 1$ & $\mathrm{NaOH}^{\mathrm{b}, \mathrm{c}}$ & 0.02 & 65 & 24 & 8 \\
\hline & & $2: 1$ & $\mathrm{NaH}$ & 1.0 & 60 & 72 & 60 \\
\hline \multirow{8}{*}{ e } & \multirow{8}{*}{$5.20[38]$} & $2: 1$ & DIPEA & 1.0 & 20 & 192 & 0 \\
\hline & & $1: 1$ & DIPEA & 1.0 & 60 & 120 & 0 \\
\hline & & $1: 1$ & DBU & 1.0 & 60 & 120 & 0 \\
\hline & & $2: 1$ & $\mathrm{NaOH}^{\mathrm{c}}$ & 1.0 & 65 & 24 & 25 \\
\hline & & $1: 1$ & $\mathrm{NaH}^{\mathrm{b}, \mathrm{d}}$ & 2.5 & 60 & 144 & 0 \\
\hline & & $1.5: 1$ & $\mathrm{NaH}^{\mathrm{b}, \mathrm{d}}$ & 1.2 & 60 & 144 & 0 \\
\hline & & $1: 2$ & $\mathrm{NaH}^{\mathrm{b}, \mathrm{d}}$ & 1.2 & 60 & 144 & 14 \\
\hline & & $1: 2$ & $\mathrm{NaH}^{\mathrm{b}, \mathrm{d}}$ & 1.2 & 60 & 168 & 62 \\
\hline \multirow[t]{3}{*}{$\mathbf{f}$} & 9.64 [39] & $1: 1$ & DIPEA & 1.0 & 20 & 120 & 97 \\
\hline & & $3: 1$ & DIPEA & 1.0 & 60 & 96 & $22^{\mathrm{e}}$ \\
\hline & & $2: 1$ & DBU & 1.0 & 20 & 72 & 0 \\
\hline \multirow[t]{3}{*}{ g } & - & $1: 1$ & TEDA & 1.0 & 20 & 120 & 0 \\
\hline & & $2: 1$ & $\mathrm{NaOH}^{\mathrm{c}}$ & 0.02 & 65 & 48 & 13 \\
\hline & & $1: 2$ & $\mathrm{NaH}^{\mathrm{b}, \mathrm{d}}$ & 1.2 & 60 & 72 & 55 \\
\hline h & 6.05 [18] & $2: 1$ & DIPEA & 1.0 & 20 & 114 & 80 \\
\hline
\end{tabular}

a $30 \mathrm{~mol} \%$ DMSO aqueous solution at $30{ }^{\circ} \mathrm{C}$, b Reaction performed under an inert $\left(\mathrm{N}_{2}\right)$ atmosphere, creaction performed in $\mathrm{MeOH}$, d $80 \%$ solution of

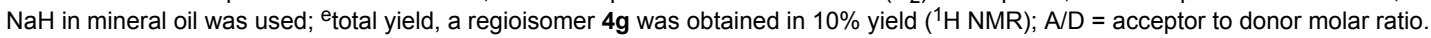


relative basicity is usually in good agreement in other polar solvents, e.g., there is a linear relationship between $\mathrm{p} K_{\mathrm{a}}$ values in water and DMF for the set of $N$-centred organic bases expressed by the equation: $\mathrm{p} K_{\mathrm{a}}(\mathrm{DMF})=0.9463 \mathrm{p} K_{\mathrm{a}}$ (water) + 1.4154 [32,33]. This semi-empirical relationship enables an initial selection of a base required for a sufficient level of deprotonation of $\mathrm{N}-\mathrm{H}$ azole acids.

1a and $\mathbf{1 b}$ as weak $\mathrm{N}-\mathrm{H}$ acids required an equimolar amount of a strong base (DBU) and reacted with 2 in stoichiometric proportions to give the appropriate products $\mathbf{3 a}$ and $\mathbf{3} \mathbf{b}$ in high purity but in low/medium yields. The presence of the unreacted substrates $\mathbf{1 a}, \mathbf{1 b}$ in the post-reaction mixtures points to the tendency of the adducts to undergo the reverse reaction - a retroMichael reaction - in equilibrium with Michael-type addition. By contrast, DIPEA, with a lower $\mathrm{p} K_{\mathrm{a}}$ gave the same adducts 3a and $\mathbf{3 b}$ in excellent yields. For $\mathbf{1 b}$ (the azole with the lowest acidity) a similar yield to $\mathbf{1 a}$ was achieved only after a significantly prolonged reaction time due to its lower concentration of the anionic form in the reaction mixture. For 1c, analogous behaviour was observed when treated with $\mathbf{2}$ in the presence of DBU. Here again, a use of DIPEA, instead of DBU, in a slight molar excess with respect to the azole furnished $3 \mathbf{c}$ in excellent yield. These conditions were also adequate in the reactions of $\mathbf{1 f}$ and $\mathbf{1 h}$ with $\mathbf{2}$ and gave the corresponding products $\mathbf{3 f}$ and $\mathbf{3 h}$ respectively, in excellent yields. No regioisomers were obtained for these $C$-nitro azole derivatives. The structure of $\mathbf{3 c}$ was established by an independent synthesis from 1,4-dinitroimidazole (4) and $\beta$-alanine methyl ester hydrochloride (5). This latter reaction proceeds via an ANRORC mechanism (Addition of Nucleophile, Ring Opening, Ring Closure) [40,41] (Scheme 2). Product 3c obtained by the two independent routes, possessed identical physicochemical and spectral properties. The observed difference in yields, $98 \%$ for Michael-type addition and $60 \%$ for ANRORC, arises from some unidentified side reactions.
In the case of the reaction of $\mathbf{1 d}$, an imidazole derivative of acidity three orders of magnitude higher compared to 1c, no reaction was observed in the presence of an equimolar amount of DIPEA and even with a four-fold molar excess of the acceptor at ambient or elevated temperature. We then carried out an additional trial in the absence of a deprotonating agent at elevated temperature on the assumption that due to the increased acidity of $\mathbf{1 d}$, a small concentration of the anionic form would be sufficient for completion of the reaction. However, gain no reaction was observed. On the other hand, the use of a catalytic amount of $\mathrm{NaOH}$ at elevated temperature furnished only a small amount of the expected product $\mathbf{3 d}$. However, when 1d was treated with a double molar excess of the acceptor in the presence of $\mathrm{NaH}$ at elevated temperature, the expected product was isolated in good yield $(60 \%)$. The reaction of the most acidic imidazole derivative within the group 1e was more complicated to optimise. DBU, DIPEA and $\mathrm{NaOH}$ all appeared as ineffective basic catalysts and only when a double molar excess of the donor was used in the presence of $\mathrm{NaH}$ was a satisfactory yield of $\mathbf{3 e}$ obtained. Similarly, for $\mathbf{1 g}$ only the former conditions gave $\mathbf{3 g}$ in good yield (62\%). Interestingly, a regioisomeric product of the addition, i.e., methyl 3-(4-bromo2-methyl-5-nitroimidazol-1-yl)propanoate (4g) was not obtained when $\mathrm{NaH}$ was used as a catalyst. However, when DIPEA was used as a base, this regioisomer was obtained in ca. $10 \%$ yield, as determined by ${ }^{1} \mathrm{H}$ NMR spectroscopy. The structures of all the products were established by means of ${ }^{1} \mathrm{H}$ and ${ }^{13} \mathrm{C}$ NMR spectroscopy.

It is worth noting that in none of the reactions polymerisation or hydrolysis of methyl acrylate was observed. Nevertheless, decreased yields for azole adducts when DBU or $\mathrm{NaH}$ were used as catalysts at elevated temperature could originate from a reversibility of the Michael reaction since unreacted azoles were isolated. This observation is in a good agreement with our
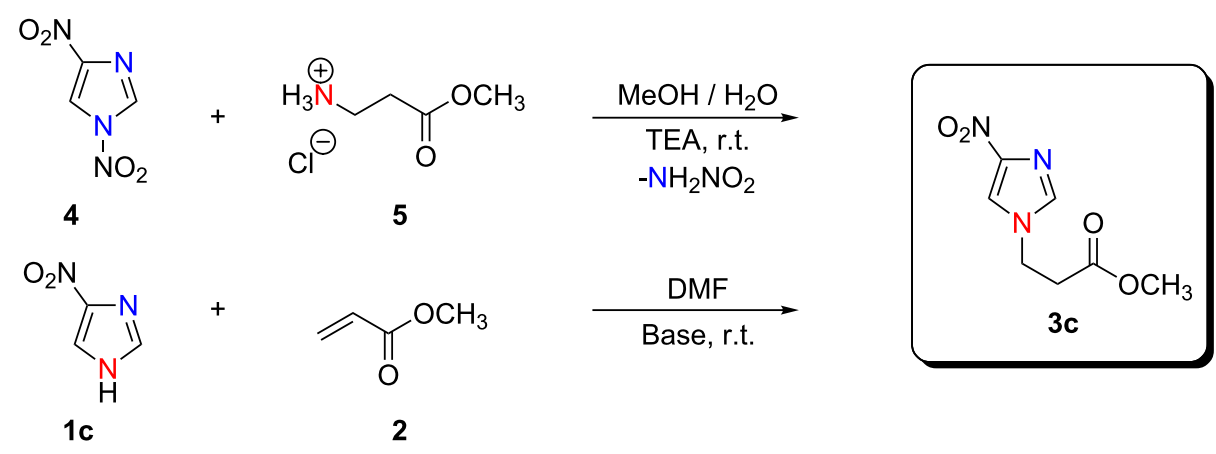

Scheme 2: Chemical evidence for a regioselective Michael-type addition of 4(5)-nitroimidazole (1c) to methyl acrylate (2) based on the ANRORC reaction of 1,4-dinitroimidazole (4) with $\beta$-alanine methyl ester hydrochloride (5). 
recent findings for Michael-type addition of uracils to acrylic acceptors $[27,42]$, where a a strongly basic catalyst (DBU) enabled control of regioselectivity via a retro-Michael reaction.

\section{Conclusion}

We have developed and optimised a simple and effective synthetic protocol for Michael-type addition of azoles of broadscale acidity including pyrazole, imidazole and 1,2,4-triazole derivatives. Importantly, for 4(5)-nitroimidazole, 2-methyl4(5)-nitroimidazole, 4(5)-bromo-2-methyl-5(4)-nitroimidazole and 3-nitro-1,2,4-triazole no regioisomers were obtained. The adducts constitute biologically active model compounds themselves and which, after acidic hydrolysis [43], can be anchored to drug delivery systems, including, e.g., chemically modified carbon nanotubes, via amide bonds.

\section{Supporting Information}

\section{Supporting Information File 1}

Experimental part.

[http://www.beilstein-journals.org/bjoc/content/

supplementary/1860-5397-7-24-S1.pdf]

\section{Acknowledgements}

Authors thank the Ministry of Science and Higher Education in Poland (grant No. NN 507415537) for the financial support.

\section{References}

1. Desiraju, G. R.; Gopalakrishnan, B.; Jetti, R. K. R.; Nagaraju, A.; Raveendra, D.; Sarma, J. A. R. P.; Sobhia, M. E.; Thilagavathi, R. J. Med. Chem. 2002, 45, 4847-4857. doi:10.1021/jm020198t

2. Katritzky, A. R.; Rees, C. W. Comprehensive Heterocyclic Chemistry 1984, 5, 469-498.

3. Goodgame, D. M. L.; Page, C. J.; Williams, D. J. Polyhedron 1992, 11, 2507-2515. doi:10.1016/S0277-5387(00)83571-8

4. Stauffer, S. R.; Katzenellenbogen, J. A. J. Comb. Chem. 2000, 2, 318-329. doi:10.1021/cc0000040

5. Zhang, J.; Didierlaurent, S.; Fortin, M.; Lefrançois, D.; Uridat, E.; Vevert, J. P. Bioorg. Med. Chem. Lett. 2000, 10, 1351-1355. doi:10.1016/S0960-894X(00)00232-8

6. Potts, K. T. Chem. Rev. 1961, 61, 87-127. doi:10.1021/cr60210a001

7. Xu, J.-M.; Qian, C.; Liu, B.-K.; Wu, Q.; Lin, X.-F. Tetrahedron 2007, 63, 986-990. doi:10.1016/j.tet.2006.11.013

8. Yang, L.; Xu, L.-W.; Xia, C.-G. Tetrahedron Lett. 2005, 46, 3279-3282. doi:10.1016/j.tetlet.2005.03.112

9. Bartoli, G.; Bartolacci, M.; Giuliani, A.; Marcantoni, E.; Massaccesi, M.; Torregiani, E. J. Org. Chem. 2005, 70, 169-174. doi:10.1021/jo048329g

10. Díez-Barra, E.; Guerra, J.; Hornillos, V.; Merino, S.; Tejada, J. Tetrahedron Lett. 2004, 45, 6937-6939. doi:10.1016/j.tetlet.2004.07.083

11. Ferreira, P. M. T.; Maia, H. L. S.; Monteiro, L. S. Tetrahedron Lett. 1999, 40, 4099-4102. doi:10.1016/S0040-4039(99)00691-7
12. Hou, X.; Hemit, H.; Yong, J.; Nie, L.; Aisa, H. A. Synth. Commun. 2010, 40, 973-979. doi:10.1080/00397910903029867

13. Cai, Y.; Yao, S.-P.; Wu, Q.; Lin, X.-F. Biotechnol. Lett. 2004, 26, 525-528. doi:10.1023/B:BILE.0000019562.21256.39

14. Martín-Aranda, R. M.; Ortega-Cantero, E.; Rojas-Cervantes, M. L.; Vicente-Rodríguez, M. A.; Bañares-Muñoz, M. A. Catal. Lett. 2002, 84, 201-204. doi:10.1023/A:1021480020425

15. Kantam, M. L.; Neelima, B.; Reddy, C. V.; Chakravarti, R. Ind. Eng. Chem. Res. 2007, 46, 8614-8619. doi:10.1021/ie070080g

16. Khabnadideh, S.; Rezaei, Z.; Khalafi-Nezhad, A.; Bahrinajafi, R.; Mohamadi, R.; Farrokhroz, A. A. Bioorg. Med. Chem. Lett. 2003, 13, 2863-2865. doi:10.1016/S0960-894X(03)00591-2

17. Begtrup, M.; Larsen, P. Acta Chem. Scand. 1990, 44, 1050-1057. doi:10.3891/acta.chem.scand.44-1050

18. Kofman, T. P.; Kartseva, G. Y. Russ. J. Org. Chem. 2001, 37, 707-716. doi:10.1023/A:1012460103654

19. Chu, T.; Hu, S.; Wei, B.; Wang, Y.; Liu, X.; Wang, X. Bioorg. Med. Chem. Lett. 2004, 14, 747-749. doi:10.1016/j.bmcl.2003.11.017

20. Sukhanov, G. T.; Sukhanova, A. G.; llyasova, Y. V. Chem. Heterocycl. Compd. 2006, 42, 1197-1199. doi:10.1007/s10593-006-0225-9

21. Ono, Y.; Izawa, Y.; Fu, Z.-H. Catal. Lett. 1997, 47, 251-253. doi:10.1023/A:1019065323538

22. Duan, Z.; Xuan, X.; Li, T.; Yang, C.; Wu, Y. Tetrahedron Lett. 2006, 47, 5433-5436. doi:10.1016/j.tetlet.2006.05.182

23. Qian, C.; Xu, J.-M.; Wu, Q.; Lv, D.-S.; Lin, X.-F. Tetrahedron Lett. 2007, 48, 6100-6104. doi:10.1016/j.tetlet.2007.06.164

24. Martín-Aranda, R. M.; Vicente-Rodríguez, M. A.; López-Pestaña, J. M.; López-Peinado, A. J.; Jerez, A.; López-González, J. de D.; Bañares-Muñoz, M. A. J. Mol. Catal. A: Chem. 1997, 124, 115-121. doi:10.1016/S1381-1169(97)00070-8

25. Liu, B. K.; Wu, Q.; Qian, X. Q.; Lv, D. S.; Lin, X. F. Synthesis 2007, 17, 2653-2659. doi:10.1055/s-2007-983816

26. Boncel, S.; Mączka, M.; Walczak, K. Z. Tetrahedron 2010, 66, 8450-8457. doi:10.1016/j.tet.2010.08.059

27. Boncel, S.; Osyda, D.; Walczak, K. Z. Beilstein J. Org. Chem. 2007, 3, No. 40. doi:10.1186/1860-5397-3-40

28. Granitza, D.; Beyermann, M.; Wenschuh, H.; Haber, H.; Carpino, L. A.; Truranb, G. A.; Bienerta, M. J. Chem. Soc., Chem. Commun. 1995, 21 , 2223-2224.

29. Perrin, D. D. Dissociation constans of organic acids and bases; Butterworths: London, 1965 Supplement 1972

30. Smith, M. B.; March, J. March's Advanced Organic Chemistry: Reactions, Mechanisms, and Structure, 5th ed.; Wiley-Interscience, 2001.

31. Benoit, R. L.; Lefebvre, D.; Fréchette, M. Can. J. Chem. 1987, 65, 996-1001. doi:10.1139/v87-170

32. Kolthoff, I. M.; Chantooni, M. K., Jr.; Smagowski, H. Anal. Chem. 1970, 42, 1662.

33. Granitza, D.; Beyermann, M.; Wenschuh, H.; Haber, H.; Carpino, L. A.; Truranb, G. A.; Bienerta, M. J. Chem. Soc., Chem. Commun. 1995, 21 , 2223-2224.

34. Vokin, A. I.; Lopyrev, V. A.; Shulunova, A. M.; Komarova, T. N.; Turchaninov, V. K. Russ. Chem. Bull. 1997, 46, 834-836. doi:10.1007/BF02495226

35. Elguero, J.; Yranzo, G. I.; Laynez, J.; Jimenez, P.; Menendez, M.; Catalan, J.; De Paz, J. L. G.; Anvia, F.; Taft, R. W. J. Org. Chem. 1991, 56, 3942-3947. doi:10.1021/jo00012a030 
36. Li, W.; Norris, B. C.; Snodgrass, P.; Prasad, K.; Stockett, A. S.; Pryamitsyn, V.; Ganesan, V.; Bielawski, C. W.; Manthiram, A. J. Phys. Chem. B 2009, 113, 10063-10067. doi:10.1021/jp904192t

37. Bowden, K.; Brownhill, A. J. Chem. Soc., Perkin Trans. 21997, 219-221. doi:10.1039/a605649k

38. Vargeese, C.; Carter, J.; Yegge, J.; Krivjansky, S.; Settle, A.; Kropp, E.; Peterson, K.; Pieken, W. Nucleic Acids Res. 1998, 26, 1046-1050. doi:10.1093/nar/26.4.1046

39. Yang, S. J. West China Univ. Med. Sci. 1999, 30, 345-346.

40. Gondela, A.; Walczak, K. Carbohydr. Res. 2005, 340, 1379-1385. doi:10.1016/j.carres.2005.03.005

41. Gondela, A.; Walczak, K. Tetrahedron: Asymmetry 2005, 16, 2107-2112. doi:10.1016/j.tetasy.2005.05.009

42. Boncel, S.; Gondela, A.; Walczak, K. Synthesis 2010, 10, 1573-1589. doi:10.1055/s-0029-1218757

43. Boncel, S.; Walczak, K. Nucleosides, Nucleotides Nucleic Acids 2009, 28, 103-117. doi:10.1080/15257770902736467

\section{License and Terms}

This is an Open Access article under the terms of the Creative Commons Attribution License

(http://creativecommons.org/licenses/by/2.0), which permits unrestricted use, distribution, and reproduction in any medium, provided the original work is properly cited.

The license is subject to the Beilstein Journal of Organic Chemistry terms and conditions:

(http://www.beilstein-journals.org/bjoc)

The definitive version of this article is the electronic one which can be found at: doi:10.3762/bjoc. 7.24 